\title{
NOTE
}

\section{Fecal Examinations for Diagnosis of Canine Parvovirus Infection}

\author{
Masami MOCHIZUKI, Showko HIDA, Shih-wei HSÜAN, and Heiji SATO \\ Laboratory of Veterinary Microbiology, Faculty of Agriculture, Kagoshima University, Korimoto 1-21-24, Kago- \\ shima 890 , Japan
}

(Received 19 December 1983/Accepted 27 April 1984)

\begin{abstract}
Seventy canine fecal samples were examined by several laboratory methods for establishing a proper diagnostic test for canine parvovirus (CPV) infection. Immune electron microscopy (IEM) was a very reliable laboratory tool for diagnosis of canine viral enteritis, but in the CPV enteric infection, fecal hemagglutination and subsequent hemagglutination-inhibition tests with a reference immune serum were comparable to IEM in respect of specificity, rapidity and expense. Picornavirus-like or astroviruslike particles were also detected in some samples.-Key words: canine parvovirus, immune electron microscopy.
\end{abstract}

Jpn. J. Vet. Sci. 46(4): 587-592, 1984

With respect to the canine enteritides, coronavirus and/or parvovirus have been frequently recognized in feces [2], on the other hand viral particles which may be new causal agents for the canine enteric diseases have been also detected $[6,7,12,13]$. However, recent canine parvovirus (CPV) infection, in which enteritis is a predominant clinical manifestation, has been most remarkable in respect of its pandemy in a short period not excepting Japan [3]. Although authors already investigated the status of CPV infection in Kagoshima area, etiological determination of viral agents of the diarrhea was not always so easy. Electron microscopy (EM) has been generally applied and considered to be the best diagnostic method, but appropriate facilities are necessary and it is relatively timeconsuming to warrant a confirming diagnosis. The present paper describes the results of stool examinations for CPV diagnosis by hemagglutination (HA) test, EM, immune EM (IEM) and virus isolation in cell cultures.

Sixty-five diarrheal fecal samples were collected from dogs requested to be diagnosed whether CPV was concerned in their di- arrhea, which were submitted by veterinary practitioners in Kagoshima, Veterinary School of Miyazaki University and the Institute of Laboratory Animal Science, Faculty of Medicine, Kagoshima Univeristy, during last one year. In the experiments, additional 5 fecal samles were collected from clinically normal experimental dogs and utilized as the negative control.

The fecal specimens were suspended in nine parts of Eagle's MEM which contained calf serum and antibiotics, then agitated vigorously for a few minutes. The suspension was clarified by a differential centrifugation at $3,000 \mathrm{rpm}$ and $10,000 \mathrm{rpm}$ for 10 minutes, respectively. The resulting supernatant was examined by HA test with swine erythrocytes and virus isolation in CRFK (Crandell feline kidney) cell culture. Hemagglutination-inhibition (HI) test with an antiserum against CPV Cp49 strain [3] and EM after negative-staining were performed when the sample showed positive HA. In addition several samples were further examined by virus isolation with feline embryonic fibroblast (FEA), secondary dog kidney 


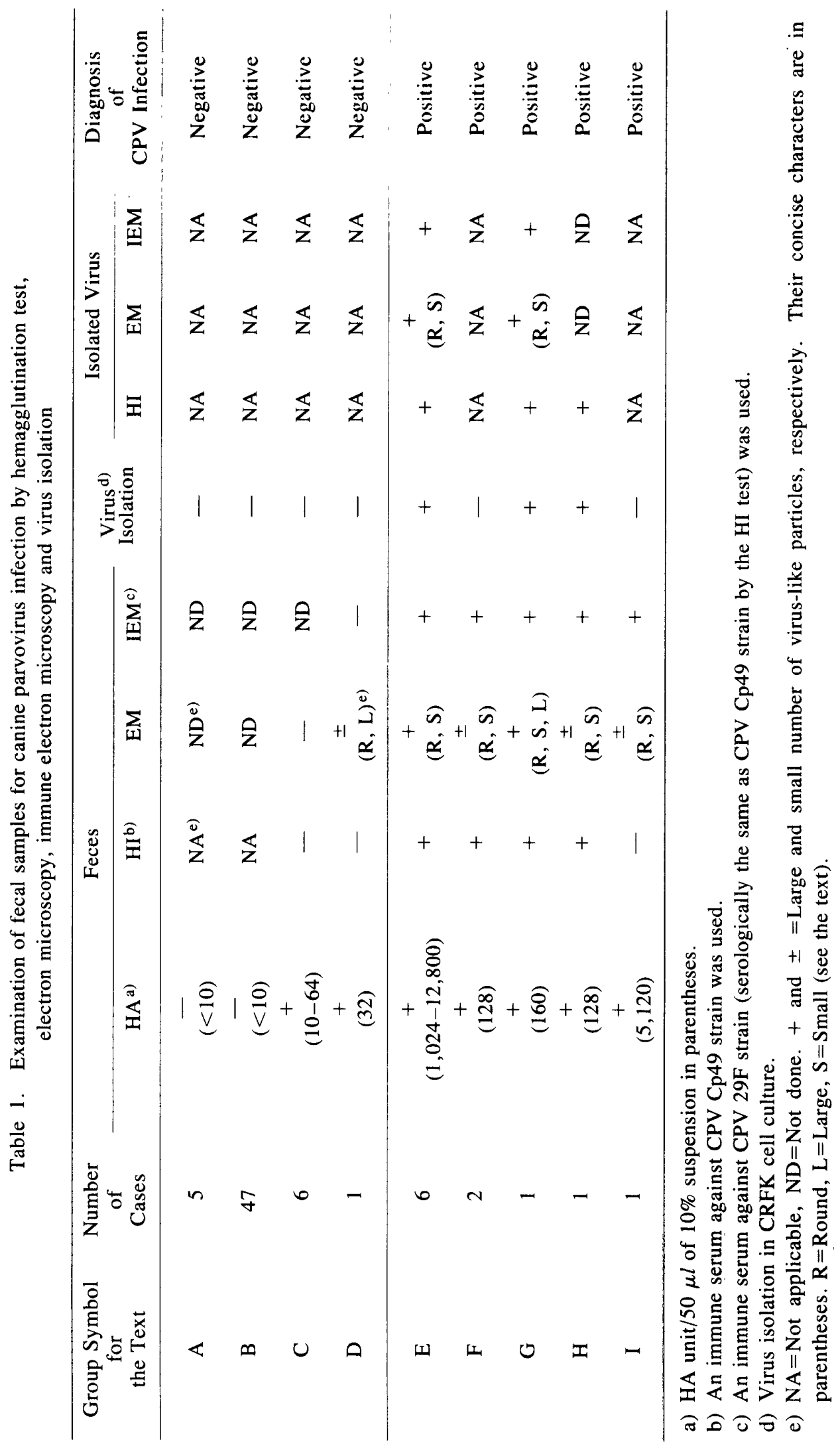




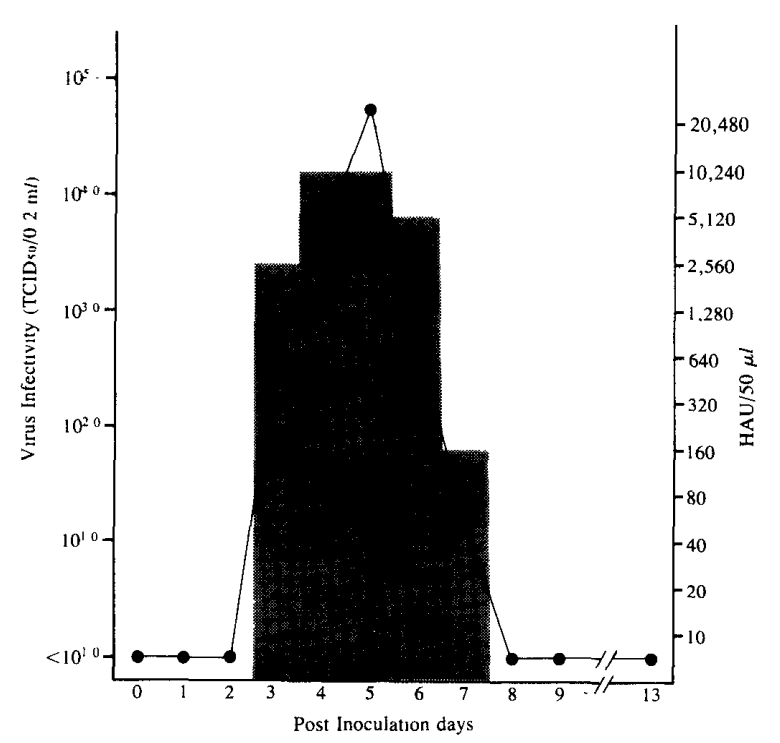

Fig. 1. Fecal viral shedding measured by the HA test (shaded portion) and the virus infectivity assay (-) in 2 pups experimentally infected with CPV KS5703 strain. Both HAU and infectivity titer were expressed as the mean value of the pups.

(DK) and MDCK (Madin-Darby canine kidney) cell cultures, and by IEM with an antiserum against CPV 29F strain [1]. The immune rabbit serum to the virus prepared by $\mathrm{CsCl}$ density gradient purification was used in IEM. The specificity of this immune serum was primarily confirmed by known CPV strains [1, 3] in HI test and IEM. After a mixture of $50 \mu l$ of the fecal sample concentrated about 50 times by ultracentrifugation (Hitachi RPS 50 rotor, at $30,000 \mathrm{rpm}$ for 1 hour) and $10 \mu l$ of the immune serum was incubated at room temperature for $30 \mathrm{~min}$ utes, EM examination was carried out. The methods of $\mathrm{HA}$ and $\mathrm{HI}$ tests, virus isolation and infectivity assay, virus purification and EM have been described previously [9-11].

Fecal viral shedding measured by the HA test and the virus infectivity assay in 2 pups intravenously infected with 5,000 HA units of our own CPV KS5703 strain is shown in Fig. 1. There was a good correlation between both tests, and the HA test could be applied for virus detection and quantification in feces instead of time-consuming and laborious assay of the virus infectivity.

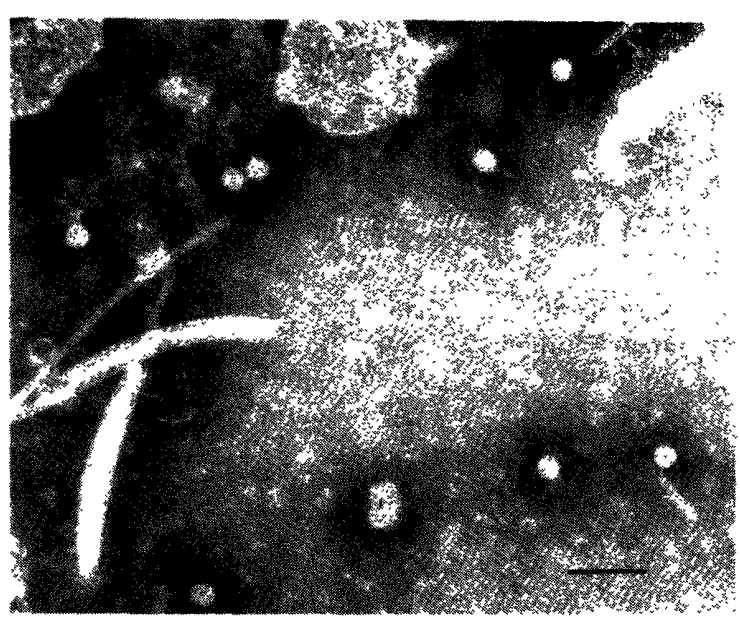

Fig. 2. Virus-like particles about $28 \mathrm{~nm}$ in diameter observed in a specimen of group D. Bars in Fig. 2 to Fig. 6 indicate $100 \mathrm{~nm}$, and the samples were negatively stained with $2 \%$ neutral phosphotungstic acid.

Summary of the results obtained by several diagnostic methods on 70 fecal samples is presented in Table 1. Five samples of group A were the negative controls, in which HA titer was less than 10 and no CPV was isolated.

Fourty-seven out of 65 field cases were diagnosed as negative of CPV infection since no HA nor virus isolation was recorded.

Six samples of group $\mathrm{C}$ showed positive HA (1:10-64), however, these HAs' were not inhibited by the anti-CPV immune serum and neither virus isolation nor EM was positive. Although a specimen of group D was similar to those of group C, only a small number of virus-like particles about $28 \mathrm{~nm}$ in diameter were detected by EM (Fig. 2). Diagnosis of CPV infection for the case was negative, because no virus was isolated in the cell culture and the particles were not aggregated by the anti-CPV immune serum in IEM.

All of group $\mathrm{E}$ were diagnosed as typical CPV infections since every diagnostic methods showed positive results. Fig. 3 shows CPV particles in one of the fecal samples by EM. Numerous virus particles were observed and their average diameter was about $20 \mathrm{~nm}$.

Though HA was successfully inhibited by the anti-CPV immune serum in the specimen 


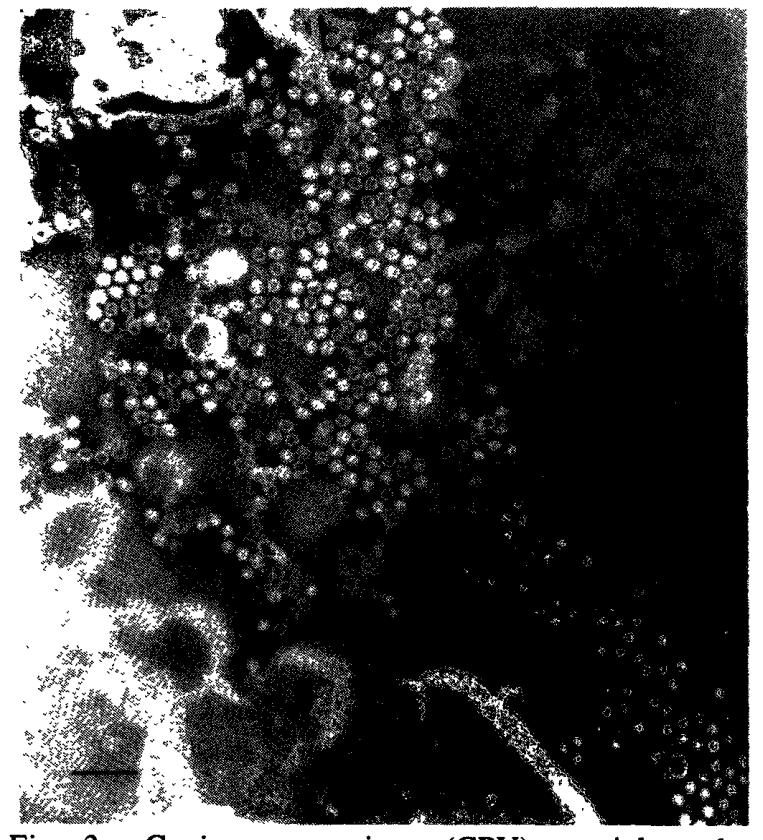

Fig. 3. Canine parvovirus (CPV) particles about $20 \mathrm{~nm}$ in diameter observed in one of the fecal samples of group E.

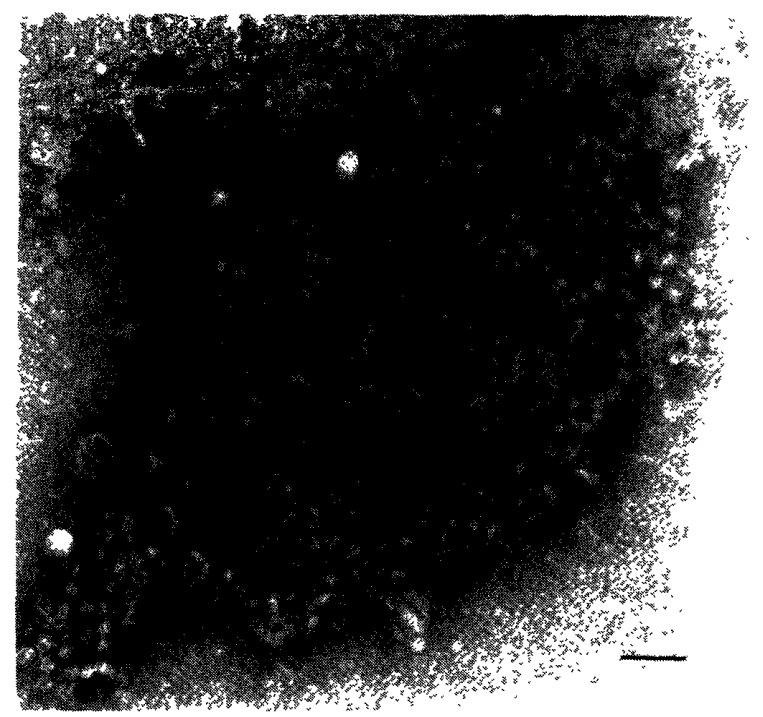

Fig. 5. Immune electron microscopy of the fecal sample of group $\mathrm{G}$ with the anti-CPV immune serum.

of group $\mathrm{F}$, the virus isolation was negative. Nevertheless these 2 cases were diagnosed as positive CPV infection since a small number of virus-like particles, possibly CPV, were observed by EM and positive results were obtained by IEM. The reason of negative virus isolation is uncertain, however, it may come from autointerference by empty particles which have been observed a lot, but not

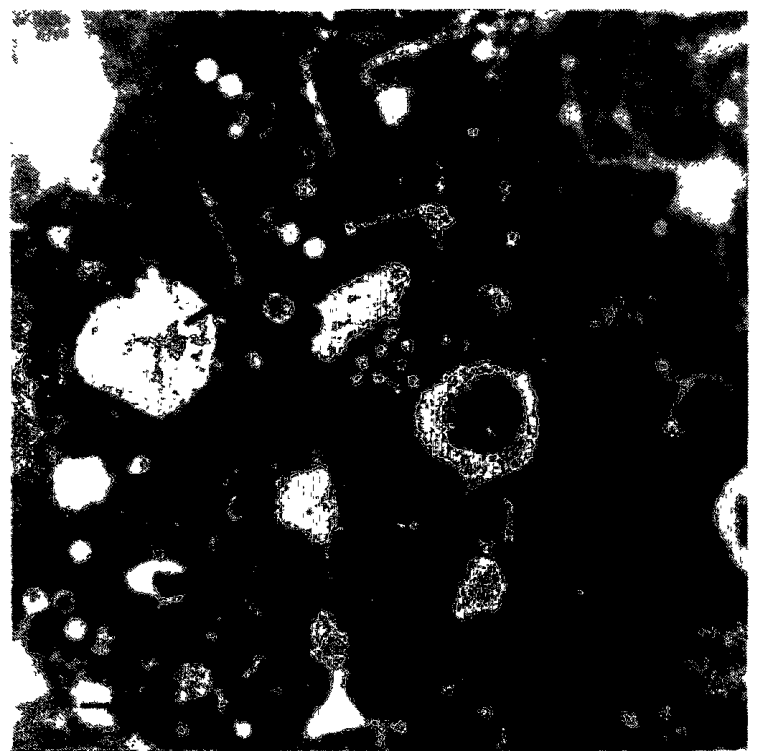

Fig. 4. Particles with different size observed in a fecal sample of group G. Arrow indicates the large viruslike particles which diameter is about $28 \mathrm{~nm}$.

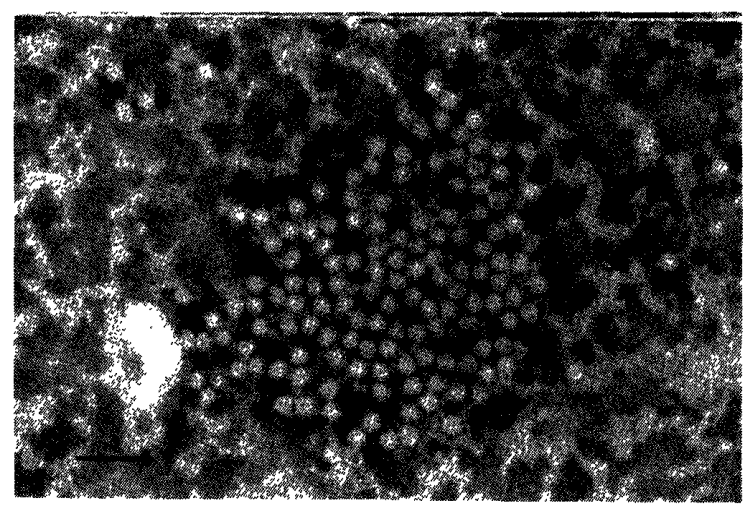

Fig. 6. CPV particles isolated in CRFK cell culture from the sample of group $\mathrm{G}$.

all, in IEM. Viral neutralization or aggregation by coproantibodies [5] is unlikely since the HA test has been positive and virus particles have been sparsely observed by EM.

A specimen of group $\mathrm{G}$ can belong to group $\mathrm{E}$, however, virus-like particles with obviously different size were observed by EM as shown in Fig. 4. The large particles in Fig. 4 were similar to those observed in group D (Fig. 2). Although these large virus-like particles could not be identified since their precise morphology was unclear, they might be picorna-like virus [6] or astro-like virus [7, 13], when taking only their overall sizes into consideration. The small particles were con- 
sidered to be CPV because they were aggregated by the anti-CPV immune serum (Fig. 5) and the large particles were not, furthermore the small particles could grow in the cell culture (Fig. 6) and they were again aggregated by the anti-CPV immune serum in IEM.

A specimen of group $\mathrm{H}$ was essentially the same as those of group E, however, the results of EM and IEM were not strongly positive. Two virus strains of group $\mathrm{G}$ and $\mathrm{H}$ had a remarkable biological characteristic. They could propagate well with distinct cytopathic effect even when inoculated into CRFK cell culture in which the cells had seemingly formed a monolayer, although they have been passaged in vitro only 3 times so far. Experiments of their pathogenicities in vivo and in vitro, and an identification of the large virus-like particles are now in progress.

Notwithstanding high HA activity, the HA was not inhibited by the anti-CPV immune serum in a specimen of group I. No virus was isolated in CRFK, FEA, MDCK nor DK cell cultures, but a few CPV-like particles were detected by EM, and IEM showed a positive result. No possible explanation was available for this case, however, IEM clearly demonstrated the presence of CPV in the feces, and it was reasonable to diagnose that CPV was concerned in the diarrhea.

From these results, it has proved that IEM is a very reliable laboratory tool for diagnosis of enteric viral diseases, however, at least in the case of CPV enteric infection, HA and subsequent $\mathrm{HI}$ tests with a reference immune serum on fecal samples in the present study are considered to be comparable to IEM in respect of specificity, rapidity and expense.

The present results are well consistent with studies reported previously $[4,8]$ and it has been confirmed that fecal $\mathrm{HA} / \mathrm{HI}$ tests are quite convenient diagnostic methods for CPV infection. However, it is worthy to note that there have been some contradiction among results when the plural diagnostic tools have been applied on fecal samples as reported here, and it should be taken notice that, when the diagnosis starts, canine diarrhea may result from complex pathogens.

ACKNOWLEDGMENTS: The authors wish to thank Professor Shin-ichiro Konishi, University of Tokyo, and Dr. Masayuki Ajiki, Kyoto-Biken Laboratories, for supplies of the CPV Cp49 strain and an immune serum against it, and CPV 29F strain, respectively.

\section{REFERENCES}

1. Ajiki, M., Takamura, K., Hiramatsu, K., Nakai, M., Sasaki, N., and Okuma, S. 1983. J. Jpn. Vet. Med. Assoc. 36: 68-73.

2. Appel, M. J. C., Cooper, B. J., Greisen, H., Scott, E., and Carmichael, L. E. 1979. Cornell Vet. 69: 123-133.

3. Azetaka, M., Hirasawa, T., Konishi, S., and Ogata, M. 1981. Jpn. J. Vet. Sci. 43: 243-255.

4. Carmichael, L. E., Joubert, J. C., and Pollock, R. V. H. 1980. Am. J. Vet. Res. 41: 784-791.

5. Eugster, A. K. 1980. Am. J. Vet. Res. 41: 20202024.

6. Eugster, A. K., and Sidwa, T. 1979. Vet. Med. Small Anim. Clin. 74: 817-819.

7. Hammond, M. M., and Timoney, P. J. 1983. Cornell Vet. 73: 82-97.

8. Klingeborn, B., and Moreno-López, J. 1980. Zbl. Vet. Med. B, 27: 483-488.

9. Konishi, S., Mochizuki, M., and Ogata, M. 1975. Jap. J. Vet. Sci. 37: 439-449.

10. Mochizuki, M., Konishi, S., and Ogata, M. 1977. Jap. J. Vet. Sci. 39: 27-37.

11. Mochizuki, M., Konishi, S., and Ogata, M. 1978. Jap. J. Vet. Sci. 40: 375-383.

12. Timoney, P. J., Hammond, M. M., Peterson, B. L., Jones, L. A., Sieber, S. G., and Carmichael, L. E. 1983. Vet. Rec. 113: 318-319.

13. Williams, F. P., Jr. 1980. Arch. Virol. 66: 215226. 
要 約

䔬便を用いたイヌパルボウイルス感染症の診断 (短報)：望月雅美・日田祥子・宣 世緯・佐藤平二（鹿児島 大学農学部獣医学科家畜微生物学講座 $一$ —イヌパルボウイルス（CPV）による下痢症の簡便, 迅速かつ正確な 診断法開発のため, 合計70例の翼便に種々の検查法を応用した絬果，免疫電子影徽鏡観察法 (IEM) は優れたウ イルス性下痢症診断法であることがわかった。さらに，糞便材料を用いて実施した血球凝集反応陽性例について 特異免疫血清による血球凝集阻止試験で特異性を検討する方法が，CPVによる下麻店の診断には IEM と同程 度に有用であることが確認された。 